\title{
Hate Speech And Ethno-Religious Conflicts In Nigeria: Implications For Political Stability
}

\author{
Nkechi G. Onah, ${ }^{1}$ Innocent A. Ugwu, ${ }^{2}$ Favour C. Uroko ${ }^{3}$ \\ ${ }^{123}$ Department of Religion and Cultural Studies, University of Nigeria, Nigeria \\ Email:favour.uroko@unn.edu.ng
}

\begin{abstract}
:
While freedom of expression or free speech is a fundamental human right of all, hate speech heralds danger for a country. Using a qualitative research approach, this study examines the connection between hate speech, ethno-religious conflicts, and political stability in Nigeria. This study argues that the threat to internal security in Nigeria is a resultant effect of social injustice in the country. In Nigeria, hate speech has been on the increase instigating ethnic and religious sentiment, mistrust, and conflicts. The study suggests that peace, social justice and political inclusion should be adopted in running the affairs of the nation.
\end{abstract}

Article History:
Received: 7 November 2020
Accepted: 30 July 2021
Keywords:
hate speech;
national stability;
religion;
free speech;
ethnicity;
violence.
.

\section{Introduction}

Before the coming of the British to Nigeria, people lived in separate entities in form of ethnic groups. The three major ethnic groups in Nigeria are: Igbo, Hausa and Yoruba. Nigeria has over 250 ethnic groups. Each of these ethnic groups speaks a different language and shares different cultural affiliations with each other." Beyond the three major ethnic groups, Igala, Ijaw, Urhobo, Itsekiri,Modakeke, Nupe, Kanuri, Ogoni,Kataf, Tiv, Gwari, Jukar, Edo, Efik, Idoma, Jukun, Biron, Aguna and have significant population in Nigeria. ${ }^{2}$ Each of the ethnic groups in Nigeria has its own language, dressing pattern, type of food, religion etc. The different ethnic groups in Nigeria had their own different systems of political administration. While the Fulani and the Yoruba people have centralized system of administration headed by an Emir and Oba respectively, the Igbo people had participatory democracy which is government by the elders called gerontocracy. ${ }^{3}$

The British ruled Nigeria until 1960 when Nigeria got her independence. At the start of Nigeria's political independence in 1960, the struggle for state power and struggle for scarce resources intensified the level of hatred between the major ethnic groups. ${ }^{4}$ Since then,

${ }^{1}$ F.O. Enem, C.C. Mba, M.C. Obeta, and M.C. Ezema. New perspective on the Social Sciences. (Enugu: Calvaryside Printing and Publishing Co, 1995), 87.

${ }^{2}$ F.O. Enem, C.C. Mba, M.C. Obeta, and M.C. Ezema. New perspective on the Social Sciences.

${ }^{3}$ A.O. Ojo. Political Science and Government of Nigeria. (Nigeria: Ilesanmi Press \& Sons, 1973), 92-94.

${ }^{4}$ C. Ezeibe. "Hate Speech and Election Violence in Nigeria." Journal of Asian and African Studies (2020): 1. https://doi.org/10.1177/0021909620951208. 
Nigeria has witnessed series of conflicts and prominent among them was the civil war between 1967 and 1970 orchestrated by 1966 coup and counter-coup leading to the declaration of the sovereign state of Biafra on 30 May 1967 and the eruption of the civil war. ${ }^{5}$ Other major conflicts have also taken place in the country. For example, Maitatsine uprising of 1980 in Kano, Jimeta Maitatsine crisis of 1984, Kafanchan riot of March 1987, ZangonKataf riot of 1992, Futua crisis 1993, Kano crisis in December 1994, Kaduna riot, 2000, and Jos crisis in September 2001. While scholars have attributed ethno-religious conflicts in Nigeria to ethnic and religious bigotry, intolerance, mutual suspicion, tribalism and discrimination, ${ }^{6}$ how hate speech contributes to the escalation of ethno-religious conflicts have been understudied. This research explores how hate speech drives ethno-religious conflicts and its implications for national stability in Nigeria.

\section{Conceptual Clarification of Hate Speech}

Hate speech is an abusive and provocative word or expression against a person, group of persons, an organization, ethnic group, state or country. According to Obijiofor, ${ }^{7}$ hate speech is defined as "Speech that attacks, threatens or insults a person or group on the basis of national origin, ethnicity, colour, religion, gender, gender identity, sexual orientation or disability." Neisser ${ }^{8}$ notes that hate speech is "all communications (whether verbal, written, symbolic) that insults a racial, ethnic and political group, whether by suggesting that they are inferior in some respect or by indicating that they are despised or not welcome for any other reasons".

Merriam Webster explains that hate speech is "a speech expressing hatred on a particular group of people." ${ }^{9}$ The United Nations Committee on the elimination of racial discrimination ${ }^{10}$ noted that hate speech comprises:

(a) all dissemination of ideas based on racial or ethnic superiority or hatred by whatever means; (b) incitement to hatred, contempt or discrimination against members of a group on grounds of their race, colour, descent, or national or ethnic origin; (c) threats or incitement to violence against persons or groups on the grounds in (b) above; (d) expression of insults, ridicule or slander of persons or groups or justification of hatred, contempt or discrimination on the grounds in (b)

17.

${ }^{5}$ C. Ezeibe. "Hate Speech and Election Violence in Nigeria." Journal of Asian and African Studies (2020): 1-

${ }^{6}$ Usifo 2017; Opeyemi and Haldun 2016; Onah 2014; Onah 2017, Ray 2012; Fawole and Bello 2011.

${ }^{7}$ Obijiofor, 2018.

${ }^{8}$ Neisser, 1994

${ }^{9}$ Merriam Webster. Hate speech. Available at: https://www.merriamwebster.com’hat. Accessed 5 May 2018.

${ }^{10}$ The United Nations Committee on the elimination of racial discrimination, 2013, 4. 
above, when it clearly amounts to incitement to hatred or discrimination; (e) participation in organizations and activities which promote and incite racial discrimination.

However, every insulting language does not essentiallytranslate to hate speech. Hate speech can be "identified by the severity of what is said, the intensity of the harm advocated, the content of the communication and the public nature of the speech."11

Hate speech is now a political weapon for not only attacking one's political opponent but also crosses both ethnic and religious boundaries in Nigeria. For example, hate speech, ethnicity and religion were very significant to the 2015 general elections in Nigeria causing bloodshed, demolition, and weakened the capacity for stable governance and national unity. ${ }^{12}$

The hate speech regulation has proven to be challenging in Nigeria. The lawful frameworks intended to control hate speech, such as the 1999 constitution, the 2010 Electoral Act and the Guidelines for the Registration of New Political Parties, are used only parsimoniously in the prosecution of hatemongers. ${ }^{13}$ In 2019 the Nigerian government tried to introduce the hate speech and social media bills but the bills were rejected by the citizens. According to the proposed hate speech bill, people could face life imprisonment or death penalty.The bills were rejected because of the clash with the freedom of speech and expression as contained in the country's constitution.

\section{Causes of Hate Speech in Nigeria}

The following factors could underlie hate speeches in Nigeria:

\section{Marginalization}

Marginalization is often defined as "the process of making a group or class of people less important or relegated to a secondary position, (e.g., when one class of people is grouped together as second class citizens). ${ }^{14}$ Marginalization here entails imbalance in power by our leaders. It is a situation whereby some sections of the country are favoured more than the others. For example, in the case of President Buhari's first appointment of the Army service chiefs, it was blatantly parochial. This is because the appointments did not reflect federal

\footnotetext{
${ }^{11}$ P.O. Mbah, Nwangwu C, Ugwu S.C. and Simons G. "Contentious elections, political exclusion, and challenges of national integration in Nigeria." Cogent Social Sciences, 5:1 (2019): 10. https://doi.org/10.1080/23311886.2019.1565615.

${ }^{12}$ P.O. Mbah, Nwangwu C, Ugwu S.C. and Simons G. "Contentious elections, political exclusion, and challenges of national integration in Nigeria."

${ }^{13}$ Ikeanyibe et al., 2018.

${ }^{14}$ Granger, 2013, n.p.
} 
character as contained in the constitution of Nigeria. None of the five army service chiefs appointed by President Buhari was from the South East. This political exclusion and economic marginalization emasculate the legitimacy of democracy. In multi-ethnic and plural societies such as Nigeria, appointments into major political positions are critical rudiments of politics. ${ }^{15}$

Table 1 shows the five Army service chiefs appointed by Buhari ${ }^{16}$

\begin{tabular}{|c|c|c|c|}
\hline $\mathrm{S} / \mathrm{N}$ & POSITION & NAME & STATE OF ORIGIN \\
\hline 1 & $\begin{array}{l}\text { Chief of Defence } \\
\text { Staff (CDS) }\end{array}$ & $\begin{array}{l}\text { General Abayomi Gabriel } \\
\text { Olanishakin }\end{array}$ & Ekiti \\
\hline 2 & $\begin{array}{l}\text { Chief of Army Staff } \\
\text { (COAS) }\end{array}$ & Lt. Gen. TukurBurati & Borno \\
\hline 3 & $\begin{array}{l}\text { Chief of Air Staff } \\
\text { (CAS) }\end{array}$ & Air marshal Sadique Abubakar & Bauchi \\
\hline 4 & $\begin{array}{l}\text { Chief of Naval Staff } \\
\text { (CNS) }\end{array}$ & Vice Admiral Ibok-EteEkweIbas & Cross River \\
\hline 5 & $\begin{array}{l}\text { Chief of Defence } \\
\text { Intelligence (CDI) }\end{array}$ & $\begin{array}{l}\text { Air Marshal Monday Riku } \\
\text { Morgan }\end{array}$ & Benue \\
\hline
\end{tabular}

The appointment depicts ethnic sentiment and nepotism. On the issue of state creation, five out of the six geo-political zones in Nigeria have six or seven states except South Eastern Nigeria which has only five states. This means that the Igbo people that constitute the South Eastern Nigeria play second fiddle in a country that belongs to all. Consequently, this felt marginalization by the Igbo people of South east has led to utterance that seems harmful and or inciting. It has amplified hate speech and bigotry in the country. This continuous marginalization of Igbo ethnic group triggered the reemergence of Indigenous people of Biafra (IPOB) who are agitating for a separate state. It is worthy of note that "Biafra is a social formation constructed from class considerations which emerged in 1967, but its resurrection in 1999 explains the reinvention of old prejudices that characterize the Nigerian state." 17

Table 2 shows the number of states in each of the six geo-political zones in Nigeria. ${ }^{18}$

\begin{tabular}{|c|l|l|c|}
\hline S/N & \multicolumn{1}{|c|}{$\begin{array}{c}\text { POLITICAL } \\
\text { ZONE }\end{array}$} & \multicolumn{1}{|c|}{ STATES } & $\begin{array}{c}\text { NO OF } \\
\text { STATES }\end{array}$ \\
\hline 1 & North East & $\begin{array}{l}\text { Bauchi, Borno, Taraba, Adamawa, Gombe, } \\
\text { Yobe }\end{array}$ & 6 \\
\hline 2 & North West & Kaduna, Kano, Kastina, Kebbi, Sokoto, & 7 \\
\hline
\end{tabular}

${ }^{15}$ P.O. Mbah, Nzeadibe C.N., Nwangwu C, et.al. "Separatist threat, militarization and voter turnout: exploring the dynamics of the 2017 governorship election in Anambra state, Nigeria." Journal of Asian and African Studies. Vol.55, No.8 (2020): 1093-1107.

${ }^{16}$ Source: Adomi Ochuko and Joseph Adomi, 2017, 34.

${ }^{17}$ P.O. Mbah, Nzeadibe C.N., Nwangwu C, et.al. "Separatist threat, militarization and voter turnout: exploring the dynamics of the 2017 governorship election in Anambra state, Nigeria": 1097.

${ }^{18}$ Ibenegbu, 2017. 


\begin{tabular}{|c|l|l|c|}
\hline & & Zamfara, Jigawa & \\
\hline 3 & North Central & $\begin{array}{l}\text { Niger, Kogi, Benue, Plateu, Nasarawa, } \\
\text { Kwara, FCT }\end{array}$ & 7 \\
\hline 4 & South West & Ondo, Ogun, Osun, Oyo, Lagos and Ekiti & 6 \\
\hline 5 & South South & $\begin{array}{l}\text { Akwaibom, Bayelsa, Cross River, Rivers, } \\
\text { Edo and Delta }\end{array}$ & 6 \\
\hline 6 & South East & Enugu, Anambra, Ebonyi, Imo and Abia & 5 \\
\hline
\end{tabular}

\section{Religious Fanaticism}

Religious fanaticism is the extreme love of one's religion against another person's own religion. It is the belief that one's own religion is better than any other religion. Danfulani cited in $^{19}$ asserts that "religious fanaticism is essentially a negative and vicious attitude to religion, characterized by exaggeration and immoderation, manipulation and exploitation, excesses and violence". Religious fanaticism leads to religious intolerance which is the inability to recognize or accommodate another person's own religion. Principally ruled by the prejudices and biases for another's religion, one can make utterances highly demeaning of other religions. In the religious scenery of Nigeria, religious conflicts are rife. Nigeria is a country with people of diverse culture and religion with Christianity, Islam and African Traditional Religion (ATR). Hate speech is used to prepare the ground for religious conflicts in the country. Nigeria is a secular state and therefore for any religious sect to come out and pronounce its own religion as paramount is unlawful in Nigeria. Hence, religious fanaticism, with its disruptive and negative inclinations coupled with hateful comments has the potential to cause instability in the country.

\section{Quest for Power}

Human beings are political beings in need of power and material possessions. This is because man cannot be separated from power and affluence. During elections in Nigeria, use of hate speeches are intensified. In Nigeria elections to political positons are aggressively contested leading to hate speech and political violence during elections. Hate speech is typically aimed at raising sentiments among members of particular ethnic or religious groups and political parties before, during and after elections mainly to win political support and sympathy along divisive lines. For example, during the 2015 presidential election, leaders and supporters of the PDP and the APC used hate speech expressively to slight, discredit and defame members of the opposition groups. ${ }^{20}$ Hate speech is not only inciting, derogatory,

\footnotetext{
${ }^{19}$ Ushe 2012, 142.

${ }^{20}$ C. Ezeibe. "Hate Speech and Election Violence in Nigeria": 11.
} 
divisive, but leads to instability and militarization of elections. ${ }^{21}$ For quest for power, hate speech is sometimes used to give wrong information to citizens during election campaign.

Some of the documented hate speeches in Nigeria are shown in Tables 3 and 4 .

Table 3: Hate speeches in Northern Nigeria, $2010-2015^{22}$

\begin{tabular}{|c|c|c|c|}
\hline $\mathrm{S} / \mathrm{N}$ & Year & Hate speaker & Hate speech \\
\hline 1 & 2010 & $\begin{array}{l}\text { The former Governor of the } \\
\text { old Kaduna State, Alhaji } \\
\text { Lawan Kaita }^{23}\end{array}$ & $\begin{array}{l}\text { The North Would Make the Country } \\
\text { Ungovernable If President Goodluck } \\
\text { Jonathan wins the } 2011 \text { polls... Anything } \\
\text { short of a Northern President is } \\
\text { tantamount to stealing our presidency. }\end{array}$ \\
\hline 2 & 2010 & $\begin{array}{l}\text { Shehu Sani, a Kaduna- based } \\
\text { civil rights activist }{ }^{24}\end{array}$ & $\begin{array}{l}\text { President Goodluck Jonathan should not } \\
\text { contemplate contesting the } 2011 \\
\text { presidential election, any attempt by him } \\
\text { to contest amounts to incitement and a } \\
\text { recipe for political instability. }\end{array}$ \\
\hline 3 & 2010 & $\begin{array}{l}\text { National Coordinator of the } \\
\text { Coalition of Northern } \\
\text { Politicians, Dr. Junaidu } \\
\text { Mohammed }^{25}\end{array}$ & $\begin{array}{l}\text { It must be a Northerner or no Nigeria ... if } \\
\text { GoodluckJonathan wins the PDP's } \\
\text { endorsement to contest the } 2011 \\
\text { presidential election, there would be } \\
\text { violence. }\end{array}$ \\
\hline 4 & 2012 & $\begin{array}{l}\text { Presidential candidate of } \\
\text { Congress for Progressive } \\
\text { Change, General } \\
\text { Muhammadu Buhari }^{26}\end{array}$ & $\begin{array}{l}\text { God willing, by 2015, something will } \\
\text { happen. They either conduct a free and fair } \\
\text { election or they go a very disgraceful way. } \\
\text { If what happened in } 2011 \text { should again } \\
\text { happen in } 2015 \text {, by the grace of God, the } \\
\text { dog and the baboon would all be soaked in } \\
\text { blood. }\end{array}$ \\
\hline 5 & 2012 & $\begin{array}{l}\text { National Coordinator of the } \\
\text { Coalition of Northern } \\
\text { Politicians, Dr. Junaidu } \\
\text { Mohammed }^{27}\end{array}$ & $\begin{array}{l}\text { Unless efforts are made to ensure that the } \\
2015 \text { general election are free and fair, it } \\
\text { may turn out to be the last election in the } \\
\text { history of the nation }\end{array}$ \\
\hline 6 & 2013 & $\begin{array}{l}\text { National Coordinator of the } \\
\text { Coalition of Northern } \\
\text { Politicians, Dr. Junaidu } \\
\text { Mohammed }^{28}\end{array}$ & $\begin{array}{l}\text { There will be bloodshed. Those who feel } \\
\text { short-changed may take the war path and } \\
\text { the country may not be the same again. }\end{array}$ \\
\hline 7 & 2013 & Abu King Shuluwa ${ }^{29}$ & $\begin{array}{l}\text { Nigeria will disintegrate if Jonathan } \\
\text { contests in } 2015 .\end{array}$ \\
\hline
\end{tabular}

${ }^{21}$ Mbah et.al, 2020.
${ }^{22}$ Source: Ezeibe, 2015:15-18; Ezeibe \& Ikeanyibe, 2017:75-76; Ikeanyibe et al, 2018:102-106; Ezeibe, 2020:7-8.

${ }^{23}$ Jason, 2011.

${ }^{24}$ Victor Anya. Daily Independent, June 22, 2012. Retrieved from: http://ailyindependentnig.com/2012/06/ making-nigeriaungovernable-forpresident-jonathan

${ }^{25}$ Interview with Guardian Newspaper, $2{ }^{\text {nd }}$ November, 2010.

${ }^{26}$ Reported by LikaBinniyat in vanguard Newspaper on May $15^{\text {th }}, 2012$.

${ }^{27}$ Leadership March 29, 2012.

${ }^{28}$ Reported by KemuOguns in Osun Defender. $2^{\text {nd }}$ December, 2013

${ }^{29}$ Daily independent Friday, March $8^{\text {th }} 2013$ 


\begin{tabular}{|c|c|c|c|}
\hline 8 & 2013 & $\begin{array}{l}\text { Former Chairman of PDP, } \\
\text { Colonel Ahmadu Ali (rtd) }\end{array}$ & $\begin{array}{l}\text { The Yorubas are ungrateful kind of people, } \\
\text { who do not appreciate what others have } \\
\text { done for them. }\end{array}$ \\
\hline 9 & 2013 & $\begin{array}{l}\text { General Muhammadu } \\
\text { Buhari }^{31}\end{array}$ & $\begin{array}{l}\text { The military offensives against the Boko } \\
\text { Haram insurgents are anti-north. }\end{array}$ \\
\hline 10 & 2014 & $\begin{array}{l}\text { Vice Admiral MurtalaNyako } \\
\text { (rtd.), former governor of } \\
\text { Adamawa State }^{32}\end{array}$ & $\begin{array}{l}\text { The Jonathan's administration counter- } \\
\text { terror operation against Boko Haram } \\
\text { insurgents is tantamount to a "full-fledged } \\
\text { genocide" against the North. }\end{array}$ \\
\hline 11 & 2014 & $\begin{array}{l}\text { Governor Shema Ibrahim of } \\
\text { Kastina State }\end{array}$ & $\begin{array}{l}\text { You should not be bordered with } \\
\text { cockroaches of politics. Cockroaches are } \\
\text { only found in the toilet even at homes, if } \\
\text { you see cockroach in your house, crush } \\
\text { them }\end{array}$ \\
\hline 12 & 2014 & $\begin{array}{l}\text { An Islamic Cleric, } \\
\text { ImaSadiq }^{34}\end{array}$ & $\begin{array}{l}\text { Muslims, vote for Buhari. It is a sin to } \\
\text { support a non-Muslim }\end{array}$ \\
\hline 13 & 2014 & Northern Elder Forum ${ }^{35}$ & $\begin{array}{l}\text { Those who vote for Jonathan and the PDP } \\
\text { in } 2015 \text { will be considered an enemy of the } \\
\text { North }\end{array}$ \\
\hline
\end{tabular}

Table 4: Hate Speeches in Southern Nigeria, $2010-2015^{36}$

\begin{tabular}{|c|c|l|l|}
\hline S/N & Year & \multicolumn{1}{|c|}{ Hate speaker } & \multicolumn{1}{c|}{ Hate speech } \\
\hline 1 & 2012 & $\begin{array}{l}\text { Chinua Achebe, a } \\
\text { foremost Nigerian } \\
\text { writer }^{37}\end{array}$ & $\begin{array}{l}\text { The Igbo culture being receptive to change, } \\
\text { individualistic and highly competitive gave the } \\
\text { Igbo man an unquestionable advantage... Unlike } \\
\text { the Hausa/Fulani, he was unhindered by a wary } \\
\text { religion and unlike the Yoruba, he was } \\
\text { unhampered by traditional hierarchies. }\end{array}$ \\
\hline 2 & 2013 & $\begin{array}{l}\text { Femi Fani-Kayode, a } \\
\text { former Aviation } \\
\text { Minister }\end{array}$ & $\begin{array}{l}\text { The Igbos are collectively unlettered, uncouth, } \\
\text { uncultured, unrestrained and crude in all their } \\
\text { ways ... Money and the acquisition of wealth is } \\
\text { their sole objective and purpose in life. }\end{array}$ \\
\hline 3 & 2013 & $\begin{array}{l}\text { The leader of the Niger } \\
\text { Delta Poples Salvation } \\
\text { Force (NDPSF), Alhaji }\end{array}$ & $\begin{array}{l}\text { There will be no peace, not only in the Niger } \\
\text { Delta, but everywhere if Goodluck Jonathan is } \\
\text { not president by 2015, except God takes his life, }\end{array}$ \\
\hline
\end{tabular}

${ }^{30}$ Sun Newspaper, March 16, 2013

${ }^{31}$ This Day, Jun 03, 2013.

${ }^{32}$ Odunsi, Wale (2014) "Full text of Nyako's letter", Daily Post Newsletter, [Online] 19 April. Retrieved from: http://dailypost.ng/2014/04/19/

${ }^{33}$ Reported by Premium Times on $19^{\text {th }}$ November, 2014

${ }^{34}$ Twitter handle, Saturday, $27^{\text {th }}$ December, 2014.

${ }^{35}$ Vanguard, 15 October 2014.

${ }^{36}$ Source: Ezeibe, 2015:15-18; Ezeibe\& $E$ Ikeanyibe, 2017:75-76; Ikeanyibe et al, 2018:102-106, Ezeibe, 2020:7-8

${ }^{37}$ Achebe, Chinua, 2012, 74.

${ }^{38}$ Daily Post, August 8, 2013 


\begin{tabular}{|c|c|c|c|}
\hline & & $\begin{array}{l}\text { Mujahid Dokubo- } \\
\text { Asari }^{39}\end{array}$ & which we do not pray for. \\
\hline 4 & 2013 & $\begin{array}{l}\text { Chief Arthur Eze PDP } \\
\text { Chieftain }\end{array}$ & $\begin{array}{l}\text { That short man called Ngige, we gave him power } \\
\text { and he joined the Awolowo people; the people } \\
\text { that killed Igbos }\end{array}$ \\
\hline 5 & 2014 & Asiwaju Bola Tinubu ${ }^{41}$ & $\begin{array}{l}\text { It is going to be rig and roast. We are prepared } \\
\text { not to go to court but drive them out }\end{array}$ \\
\hline 6 & 2014 & $\begin{array}{l}\text { Former Governor of } \\
\text { Akwalbom State, } \\
\text { Godswill Akpabio }^{42}\end{array}$ & $\begin{array}{l}\text { Those who want to take power through the } \\
\text { back door will die. They will die }\end{array}$ \\
\hline 7 & 2014 & $\begin{array}{l}\text { South East Self } \\
\text { Determination } \\
\text { Coalition }(\text { SESD) })^{43}\end{array}$ & $\begin{array}{l}\text { We assure those cold blooded murderers that } \\
\text { this time, their blood thirsty campaign will not } \\
\text { go un-replied }\end{array}$ \\
\hline 8 & 2014 & $\begin{array}{l}\text { Alhaji Mujahid } \\
\text { Dokubo-Asari }^{44}\end{array}$ & $\begin{array}{l}2015 \text { is more than do-or-die. You are a man and I } \\
\text { am a man, we are going to meet at the battlefield }\end{array}$ \\
\hline 9 & 2014 & $\begin{array}{l}\text { Alhaji Mujahid } \\
\text { Dokubo-Asari }\end{array}$ & $\begin{array}{l}\text { If they contest (Northerners) they are wasting } \\
\text { their time. He who pays the piper will dictate } \\
\text { the tune. We own them. We are feeding them. } \\
\text { They are parasites. A beggar has no choice ... } \\
\text { they are beggars and parasites }\end{array}$ \\
\hline 10 & 2014 & $\begin{array}{l}\text { River State Governor, } \\
\text { Rotimi Amechi }\end{array}$ & $\begin{array}{l}\text { The challenge of the Nigerian Military is not } \\
\text { funding but corruption. Now they want to kill } \\
\text { some } 50 \text { officers for their own failure to equip } \\
\text { them properly to fight terrorism. The soldiers } \\
\text { have the right to protest for the federal } \\
\text { government's failure to fully equip them }\end{array}$ \\
\hline 11 & 2015 & $\begin{array}{l}\text { Wife of former } \\
\text { President, Patience } \\
\text { Jonathan }\end{array}$ & $\begin{array}{l}\text { Wetin him dey find again? Him dey drag with him pikin } \\
\text { mate, old man wey no get brain, him brain don die } \\
\text { patapata - what is Buhari looking for? Old man } \\
\text { that does not know his age. Your brain is dead. }\end{array}$ \\
\hline 12 & 2015 & $\begin{array}{l}\text { Wife of former } \\
\text { President, Patience } \\
\text { Jonathan }\end{array}$ & $\begin{array}{l}\text { Our people do not give birth to uncountable } \\
\text { children. Our men don't give birth to children } \\
\text { that they dump in streets. We are not like }\end{array}$ \\
\hline
\end{tabular}

\footnotetext{
${ }^{39}$ Vanguard Newspaper, May 5, 2013

${ }^{40}$ Premium Times, November 13, 2013.

${ }^{41}$ Tell, 7 July 2014.

${ }^{42}$ Punch Newspaper, $17^{\text {th }}$ July, 2014.

${ }^{43}$ Reported by Clifford Ndujihe in Vanguard.

${ }^{44}$ Newspaper, $5^{\text {th }}$ December, 2014.

${ }^{45}$ http://www.vanguardngr.com/2014/12/north-ungratefull-parasites-asari-dokubo).

${ }^{46}$ This day and Nations, Tuesday, ${ }^{\text {th }}$ December, 2014
} 


\begin{tabular}{|c|c|c|c|}
\hline & & & $\begin{array}{l}\text { people from that part of the country (apparently } \\
\text { the Northern Nigeria) }\end{array}$ \\
\hline 13 & 2015 & $\begin{array}{l}\text { Wife of former } \\
\text { President Patience } \\
\text { Jonathan }\end{array}$ & $\begin{array}{l}\text { Anybody that come and tell you changes, stone } \\
\text { that person... What you did not do in 1985, is it } \\
\text { now that old age has caught up with you that } \\
\text { you want to come and change... you cannot } \\
\text { change rather you will turn back to a baby }\end{array}$ \\
\hline 14 & 2015 & $\begin{array}{l}\text { The Governor of Ekiti } \\
\text { State, Peter } \\
\text { AyodeleFayose }\end{array}$ & $\begin{array}{l}\text { Buhari would likely die in office if elected, recall } \\
\text { that Murtala Muhammed, Sani Abacha and } \\
\text { Umaru Yar'Adua, all former heads of state from } \\
\text { the North West like Buhari, had died in office }\end{array}$ \\
\hline 15 & 2015 & Oba Akiolu of Lagos & $\begin{array}{l}\text { On Saturday, if anyone of you, I swear in the } \\
\text { name of God, goes against my wish that Ambode } \\
\text { will be the next governor of Lagos state, the } \\
\text { person is going to die inside this water... for the } \\
\text { Igbos and others in Lagos, they should go where } \\
\text { the Oba of Lagos heads to ... }\end{array}$ \\
\hline 16 & 2015 & $\begin{array}{l}\text { Dr. Abraham Ariyo, U.S } \\
\text { based Nigerian Doctor }\end{array}$ & $\begin{array}{l}\text { You see how they (Igbos) are being slaughtered } \\
\text { in South Africa. That is what is going to happen } \\
\text { to them in Lagos... When are they (Igbos) going } \\
\text { to be slaughtered in Abuja? We will continue to } \\
\text { bus them to Onitsha }\end{array}$ \\
\hline
\end{tabular}

\section{Implications of Hate Speech for Political Stability in Nigeria}

No doubt, hate speech is a major threat to democratic values, social stability and peace. ${ }^{47}$ Hate speech incites violence and threatens national unity. Hate speech has led to conflicts and genocide in Nigeria and other African countries. ${ }^{48}$ Although freedom of speech aids the exchange of diverse opinions and relevant for installing sustainable democracy; failure to control hate speech portends danger for sustaining the gains of democracy, especially in emerging democracies. ${ }^{49}$ Hate speech instigates vexation, discernment, conflicts and insecurity in the society. It is a catalyst to turmoil in any democratic government.Going by happenings in Nigeria, there have been series of hate speeches (see Tables 3 and4) and these have precipitated violence and instability in the country. The 2011, 2015 and 2019 presidential elections attest to this. In 2011, northern states witnessed pandemonium after Dr. Goodluck Jonathan was announced the winner of the presidential election.At least 800

\footnotetext{
${ }^{47}$ United Nations, 2019.

${ }^{48}$ C.C. Ezeibe. "Hate Speech and Post Electoral Violence in Africa." African Renaissance, 10 no. $2 \& 4$ (2013): 75-87.

${ }^{49} \mathrm{~N}$. Asogwa and C.C. Ezeibe. "The state, hate speech regulation and sustainable democracy in Africa: a study of Nigeria and Kenya." African Identities. (2020) DOI: 10.1080/14725843.2020.1813548.
} 
people were killed, properties destroyed and 65,000 people were displaced due to electoral violence. The three days of rioting began when supporters of Muhammadu Buhari started burning electoral commission offices and police stations following results that showed President Goodluck Jonathan winning the vote. This later deteriorated into violence between Muslims and Christians in the north. ${ }^{50}$ There were killings in Adamawa, Bauchi, Borno, Gombe, Jigawa, Kaduna, Kano, Katsina, Niger, Sokoto, Yobe, and Zamfara. ${ }^{51}$ In 2015, at least 58 Nigerians were killed in 2015 pre-election violence. ${ }^{52}$ An estimated 626 persons were killed during 2019 election. ${ }^{53}$ An increased number compared to 2015 election in the country. All these conflicts contribute to low voter turnout in elections in Nigeria. Observably, turnout during presidential election was 54\% in 2011, 44\% in 2015 and 35\% in $2019 .^{54}$

Hate speech breeds acrimony among different ethnic and religious groups and intensifies division in the country. It undermines security, peaceful existence, and socioeconomic development of the nation. In Nigeria there has always been confrontation between the Christians and Muslims. The comment attributed to, ImaSadiq, an Islamic Cleric - 'Muslims, vote for Buhari. It is a sin to support a non-Muslim 'and another comment attributed to Mohammed Buhari - 'The military offensives against the Boko Haram insurgents are anti-north' as examples, are recipes for conflict and further deepen religious polarization in the country. For about a decade now, the Boko haram group has been terrorizing Nigeria. Boko Haram, is afundamental Islamist group in the north-east whose goal is to overthrow the secular government in Nigeria and enforce an Islamic state. ${ }^{55}$ As aforementioned, Nigeria is a secular state therefore, for one or group of persons talking about spreading one type of religion is inciting violence in Nigeria. The intention of Boko Haram to establish Islamic caliphate in Nigeria has led to conflicts, genocide and human right abuse in the country. Book Harm was founded in Nigeria by Muhammed Yusuf in the year 2002 in

\footnotetext{
${ }^{50}$ Human Rights Watch, 2011.

${ }^{51}$ Human Rights Watch, 2011.

${ }^{52}$ N. Ibeh. " 58 Nigerians killed in 2015 pre-election violence so far - Rights Commission." Premium Times, February 13, 2015. Available at: https:/www.premiumtimesng.com/news/headlines/176802-58-nigerians-killed2015-pre-election-violence-far-rights-commission.html. Accessed 18 October 2020.

${ }^{53}$ K. Sanni. "626 killed during 2019 Nigeria elections." Report. Premium Times, July 30, 2019. Available at: https://www.premiumtimesng.com/news/headlines/343971-626-killed-during-2019-nigeria-electionsreport.html. Accessed 18 October 2020.

${ }^{54}$ Adekoya. Democracy has failed in Nigeria when voters no longer care who wins. 2019. Available at: https://www.theguardian.com/commentisfree/2019/mar/01/democracy-failed-nigeria-turnout-presidentialelection. Accessed 18 October 2020; P.O. Mbah, C. Nwangwu, S.C. Ugwu, and G. Simons. "Contentious elections, political exclusion, and challenges of national integration in Nigeria."

${ }^{55}$ Agbiboa, D E. Peace at dagger's drawn? Boko Haram and the state of emergency in Nigeria. Studies in Conflict and Terrorism, Vol.37, No.1 (2013): 41-67.
} 
Maiduguri, Borno state. Boko Haram started in form of Islamic religious school and later transformed into violence in $2009 .{ }^{56}$ On July 26, 2009, Boko Haram launched an attack on police station in Bauchi state. Many people died in the attack including two police officers and one soldier. ${ }^{57}$ On December 24 and 27, 2010, Boko Haram attacked central city of Jos and Maiduguri. Eighty-six people were killed in the attack. ${ }^{58}$

On 25th December, 2011, Boko Haram bombed St. Theresa's church, Madalla in Suleja, Niger state. A total of thirty-five people died in the attack. ${ }^{59}$ In 2012, Boko Haram bombed a police outpost at Sheka in Kano state. The attack led to fierce shooting between security forces and members of Boko Haram sect leaving more than two hundred persons dead. ${ }^{60}$ In 2013, Boko Haram killed two Nigerian soldiers and wounded five of them in a bomb attack in central Kogi state. ${ }^{61}$

On 25 May, 2014, Boko Haram attacked and killed fifty-four people while several others were injured in Yobe state. ${ }^{62}$ On December, 2015, Boko Haram shot and killed nine people in two villages (Tadagara and Dunbulwa) in Yobe state. They set many houses on fire. They also shot and killed nine fishermen in Maiduguri. ${ }^{63}$ In 2016, Boko Haram militants attacked and killed at least thirty people in two villages in Borno state. They also kidnapped women and children. ${ }^{64}$ They attacked and killed eight people outside a church in Kwamjilari village in Chibok, Borno state. Many people ran into the bush with gunshot wounds. ${ }^{65}$ In 2017, Boko Haram attacked University of Maiduguri and some local government areas in Borno state. During the attack, many people died and properties worth millions of naira destroyed. ${ }^{66}$ Records show that between 2009 and 2017, Boko Haram has been unleashing serious attacks on the Northern parts of the country especially the North-east. They attack religious groups, police stations, banks, schools, markets and government installations.

\footnotetext{
${ }^{56} \mathrm{~J}$ O. Ajayi. "The Boko haram insurgence in Nigeria and the threat to national security." AFRREV IJAH: An International Journal of Arts and Humanities, Vol.2, No.2 S/No6 (2013): 1-20.

${ }^{57}$ Vanguard, 2011

${ }^{58}$ Vanguard, 2012

${ }^{59}$ Vanguard, 2011.

${ }^{60}$ Mamah, K E. Boko Haram bombs Kano Afresh - Vanguard News, January 24, 2012. Available at: https:/www.vanguardngr.com/2012/01/boko-haram-bombs-kano-afresh/. Accessed 12 July 2018).

${ }^{61}$ Irin news, 2013.

${ }^{62}$ The Nation Newspaper, 2014.

${ }^{63}$ O.T. Kamal. "Chronology of Boko Haram attacks." The Guardian Nigeria, 13 December 2015. Available at: https:/guardian.ng/news/chronology-of-boko-haram-attacks. Accessed 15April 2018.

${ }^{64}$ Abubakar. Boko haram attacks kill at least 30 locals say. 2016. Available at: https:/edition.cnn.com/2016/02/13/africa/boko-haram-attack-nigeria/index.html. Accessed l4 October, 2020.

${ }^{65}$ S. Opejobi. Boko Haram attacks church in Borno, eight people killed, 2016. Available at: https://dailypost.ng/2016/09/19/breaking-boko-haram-attacks-church-borno-eight-people-killed. Accessed 16 July 2018.

${ }^{66} \mathrm{~N}$. Marama. Timeline of Boko Haram attacks in Borno since May, 2017, 2017. Available at: https://www.vanguardngr.com/2017/08/timeline-boko-haram-attacks-borno-since-may-2017. Accessed 12 July 2018.
} 
Boko Haram kidnapped two hundred and seventy-six (276) female students from Government Secondary School in the town of Chibok in Borno state on $14^{\text {th }}$ April, $2014{ }^{67}$ Many of the kidnapped students who were not Moslems were forced to convert to Islam. They were equally forced to marry the Boko Haram members against their wishes. Chibok is a Christian village which means that majority of the kidnapped students were Christians. After the kidnap of the Chibok girls, the leader of the Boko-Haram called Abukakar Shekau said, "Allah instructed me to sell them, I will carry out his instructions. Slavery is allowed in my religion and I shall capture people and make them slaves". ${ }^{6}$

On $19^{\text {th }}$ February, 2018, Boko Haram kidnapped over one hundred female students from Federal Government Science and Technical College, Dapchi in Yobe state (BBC News, 2018, February 26). According to the BBC News, there was disagreement over the actual number of the students kidnapped. This is because a group of parents said that the total number of the missing girls were hundred and five (105) while government said that the total number of the missing girls were hundred and ten (110). Although the kidnapped female students were later released by the Boko Haram, the only Christian student among them (Leah Sharibu) was not released. ${ }^{69}$ The father of Leah Sharibu called Nata Sharibu said that the Boko Haram insurgents decided not to release his daughter because she refused to denounce Christ. He said that the insurgents gave his daughter the option of converting to Islam but she rejected it. The girl has not returned to her parents till date (News Agency of Nigeria, 2018).

Apart from kidnapping of students in order to paralyze school activities, the Boko Haram members have been causing mayhem in the country. Boko Haram insurgencies have led to the death and displacement of thousands of people and properties worth millions of naira destroyed.The terrifying activities of the Boko Haram made the Federal Government under President Goodluck Ebelle Jonathan to give the Nigerian military order to flush out the Boko Haram terrorists from their occupied areas in the north east. Fight against Boko haram has continued even in the present leadership.There is over 2.7 million internally displaced persons (IDPs) in north-east Nigeria. ${ }^{70}$ The activities of Boko haram group have led

\footnotetext{
${ }^{67}$ S. Nasir. Nigerian girl talks about her escape from Boko Haram, 2017. https://m.khaleejtimes.com>general $>n i$ Retrieved on $7 / 4 / 2018$.

${ }^{68}$ Nasir, 2017.

${ }^{69} \mathrm{New}$ Agency of Nigeria, 2018.

${ }^{70}$ UNHCR, 2020.
} 
to food insecurity, severe malnutrition, severe violations of human rights, and widespread sexual and gender-based violence in the region. ${ }^{71}$

Another point worth mentioning is the quit notice given to the Igbo people living in the north. On $7^{\text {th }}$ of June, 2017, 16 Northern Youth groups gave Igbo people living in Northern states up to October 1, 2017 to vacate the region. ${ }^{72}$ The quit notice caused row and tension in all parts of the country especially in Igbo land. Such utterances endanger the unity of Nigeria as a country. The Indigenous People of Biafra (IPOB) in their own reaction warned that if any Igbo is killed in the North as a result of the quit notice issued by Arewa Youths, "HausaFulanis will get a dose of their senseless attacks. IPOB warned the North that "Biafrans of today are not the same breed as those they massacred between 1967 and 1970 at will, without retaliation." ${ }^{73}$ The quit notice against the Igbo people created more ill-feelings and hatred between the Igbo people and the northerners. It only took the intervention of the government through security agents and well meaning Nigerians quelling the ugly situation.

The quit notice given to the Igbo people residing in the North by the Northern youth groups caused more agitation from other parts of the country. According to Odebode ${ }^{74}$ a group known as the coalition of Niger delta agitators in a reaction to the quit notice given to the Igbo people in the north threatened to resume attack on oil installations in the region. The group also said that the Northerners and the Yoruba in the Niger delta should leave the region before October 1, 2017. The group further stated that "we demand independence and sovereign republic of Niger Delta, all the companies and businesses owned by the Northerners/Yorubas in Niger Delta should be vacated before October 1, 2017."

Fulani herdsmen continuous attack on farmers and villages in almost all parts of the country could also be ascribed to ethnic and religious sentiment and acrimony between different ethnic groups in Nigeria. The comment attributed to the national president of Miyetti Allah Kautal Hore, Bello Abdullahi Bodejo, that Fulani own Nigeria and will rule the country forever ${ }^{75}$ is inflammatory and disrespectful to other ethnic groups in the country. It could be recalled that on April 25, 2016, the armed Fulani herdsmen numbering about five hundred (500) attacked and killed many people in seven villages in Nimbo in Uzo-uwani local government area of Enugu state. ${ }^{76}$ The disreputable activities of the Fulani herdsmen

\footnotetext{
${ }^{71}$ UNHCR, 2020.

${ }^{72}$ Akhaine et al, 2017.

${ }^{73}$ Opejobi, 2017.

${ }^{74}$ N. Odebode, A. Adepogbe, and O. Aliko. Niger Delta Agitators give Northerners, Yorubas Quit Notice, 2017. Available at: https://punchng.com/ndelta-agitators-give-northerners-yoruba-quit-notice. Accessed 26 July 2018.

${ }^{75}$ Dailypost, 2020.

${ }^{76}$ Thisday 2016,
} 
ranging from rape, killing, and destruction of farm cropsand displacement of farmers have drastically affected agricultural production in Nigeria. This menace purports serious threat to food security and socio-economic development of the country.

In Benue state many communities have been attacked by the Fulani herdsmen. On February 7 2016, there was Herdsmen-Farmers clash at Tombu in Buruku Local Government Area, Benue State. The community was raided leading to the death of 10 persons. ${ }^{77}$ On March 7,8, $13 \& 17$ 2016,there were another clash between the herdsmen and farmers at MbayaTombo, Benue state leading to destruction of farm crops, over 35 people died and properties were damaged. ${ }^{78}$ On February 29, the Fulani herdsmen invaded several Agatu villages and farm settlements killing children, women, men and the elderly. Over 500 villagers were said to be killed and above 7000 displaced in 10 villages including Aila, Okokolo, Akwu, Adagbo, Odugbehon and Odejo. ${ }^{79}$ The Paramount Ruler of Logo Local Government Area, Jimmy Memme stated that between July 1 and 16 the herdsmen murdered over 85 persons, including women and children, from six out of the 10 wards in the area. ${ }^{80}$ The conflicts between Fulani herdsmen and farming communities have mostly affected different areas across Middle Belt namely, Plateau, Kaduna, Taraba, Nasarawa, Adamawa, and Benue states. ${ }^{81}$

The Benue state government signed the anti-open grazing bill into law on Monday 22nd of May, 2017. The anti-open grazing law came into effect on November 1, 2017. Governor Ortom has lamented the loss of over N95 billion owing to continuous destruction mounting from clashes between herders and farmers. ${ }^{82}$ However, a group of cattle breeders, known as Miyetti Allah Kautal Hore, disagreed to the anti-open grazing law describing it as obnoxious and a recipe for anarchy. ${ }^{83}$

Bishop David Oyedepo, the General overseer of the Living Faith Church/Winner's chapel has condemned the killings by Fulani herdsmen in the country. In a threatening letter issued by the Fulani herdsmen, they declared war against Bishop David Oyedepo and Nigerians. ${ }^{84}$ According to Oyedepo, ${ }^{85}$ insulting comments by the Fulani herdsmen include:

(a) "The country will have no peace."

\footnotetext{
${ }^{77}$ Okoro, 2018.

${ }^{78}$ Okoro, 2018

${ }^{79}$ Premium Times, 2016.

${ }^{80}$ Premium Times, 2016.

${ }^{81}$ Vanguard, 2016

${ }^{82}$ Daniel, 2017

${ }^{83}$ Ameh 2017

${ }^{84}$ Oyedepo, 2018.

${ }^{85}$ Oyedepo, 2018.
} 
(b) "God has given them this land and that they have right to live anywhere, and until the colony is established, there will be no rest in Nigeria."

(c) "The cattle colony is the only solution to the crisis, whether the government or state government accept or not."

On April, 2018, suspected Fulani herdsmen killed two catholic priests and eleven (11) parishioners during attack on a church in Benue state. ${ }^{86}$ The two priests killed were: Rev. Fr. Joseph Gor and Rev. Fr. Felix Tyolaha of St. Ignatius Quasi Catholic Parish, Ukpor, Mbalom, Gwer East local government area of Benue state. The action of the killer herdsmen generated ill-feelings in the minds of all concerned Christians in Nigeria. On Tuesday, 22nd May, 2018, Christian faithful in Nigeria organized a peaceful protest in all the local government areas in Nigeria including the Federal capital territory (FCT) against the killing of the two Catholic Priests and 11 of their parishioners.

The effects of hate speech on Nigeria cannot be over emphasized. For example, the economy of the country is being affected. Wealth is power. A nation is capable of feeding her citizens only if her economy is vibrant. No country thrives in an atmosphere of insecurity and instability. ${ }^{87}$ It is obvious that hate speech and its resultant conflicts have contributed to pooreconomic growth of Nigeria. As at 2018 Nigerian GDP was 2.11\% but presently it has dropped drastically to $-6.1 \% .^{88}$

\section{Conclusion}

Hate speeches abound in Nigeria which poses a threat to the security of human lives and properties, national unity, peaceful co-existence and socio-economic development of the country. The effects of hate speech in Nigeria cannot be over emphasized. This paper has explained the concept of hate speech, and discussed its likely causes and implications for the country. The main cause of hate speech in Nigeria has been attributed to imbalance of power among different ethnic groups that make up the country. For example, the federal government has failed to address the problem of marginalization in the country. Some sections of the country such as the Igbo people feel marginalized. Hate speech incites violence and has led to conflicts in Nigeria which have claimed many lives and properties destroyed. This study noted some incidences of hate speeches which are tearing the country apart. For example, the Northern Youth groups gave the Igbo people ultimatum to leave the

\footnotetext{
${ }^{86}$ Uja, 2018.

${ }^{87}$ Onah and Okwuosa, 2016

${ }^{88}$ National Bureau of statistics, Nigeria, 2020.
} 
region on October 1, 2017. This statement generated more agitations from other parts of the country. The coalition of the Niger Delta Avengers gave the Hausa and Yoruba people an ultimatum to leave Niger Delta region on October 1, 2017. Consequently, the coalition of the Niger Delta Avengers demanded for the independence of the Niger Delta leading to clashes between them and Nigerian security agents of which many people were killed and properties destroyed.

The Fulani herdsmen noted that there will be no peace in the country unless cattle colony is established. They destroy farm crops with their cattle leading to their clash with farmers and villagers especially in the Middle Belt. Boko Haram declared their intention to establish Islamic caliphate in Nigeria. They put their intention into action by unleashing attack on government, religious groups, kidnapping of students and destruction of businesses consequently paralyzing socio-economic activities in the region. Their actions led to the death and displacement of many people in North-eastern region of Nigeria. The study therefore, suggests that for peace and stability, social justice, equity and political inclusion should be adopted in the affairs of the nation. Thus, attention should be directed towards a detribalized and participatory governance. The study also suggest that intensive effort should be made to control the use of hate speech in political campaign in Nigeria as this undermines peace, stability and sustainable development of the nation.

\section{Bibliography}

Abubakar, A. Boko haram attacks kill at least 30 locals say. 2016. https:/edition.cnn.com/2016/02/13/africa/boko-haram-attack-nigeria/index.html. Accessed 14 October, 2020.

Adekoya, R. "Democracy has failed in Nigeria when voters no longer care who wins." The Guardian, 2019. https://www.theguardian.com/commentisfree/2019/mar/01/demo cracy-failed-nigeria-turnout-presidential-election. Accessed 18 October 2020.

Adomi $\mathrm{O}$ and Adnomi, J. Current Affairs. Lagos: Ochado Platinum Nig. Ltd., 2017.

Agbiboa, D E. Peace at dagger's drawn? Boko Haram and the state of emergency in Nigeria. Studies in Conflict and Terrorism, Vol.37, No.1 (2013): 41-67.

Agina, A. "Hate speech: Minding your language in today's Nigeria." Vanguard, 2013. Available at: www.vanguardngr.com. Accessed 26 July $/ 2018$.

Ajayi, J O. "The Boko haram insurgence in Nigeria and the threat to national security." AFRREV IJAH: An International Journal of Arts and Humanities, Vol.2, No.2 (2013): 1-20. 
Asogwa, N \& Ezeibe C. "The state, hate speech regulation and sustainable democracy in Africa: a study of Nigeria and Kenya." African Identities. (2020): 1-16. https://doi.org/ 10.1080/14725843.2020.1813548.

Ameh, C. Fulani herdsmen vow to resist Benue Anti-Grazing Bill. Daily Post, 30 May, 2017. Available at: https://dailypost.ng/2017/05/30/fulani-herdsmen-vow-resist-benue-anti-grazing-bill. Accessed 11 November 2020.

BBC News. "Nigeria Dapchi School kidnappings: What we know." BBC, 2018. www.bbc.com> world-africa-434844146. Accessed 10 April 2018.

Daniel, S. "Grazing Law: Ranch your Cattle or leave Benue, Ortom Warns.” Vanguard, 1 November 2017. https://www.vanguardngr.com>News. Accessed 4 April 2018.

Enem F O, Mba, C.C, Obeta, M.C and Ezema, M.C New perspective on the Social Sciences. Enugu: Calvaryside Printing and Publishing Co., 1995.

Ezeibe, C C. "Hate Speech and Post Electoral Violence in Africa." African Renaissance, Vol.10, No.2 \& 4 (2013): 75-87. https://doi.org/10.1177/0021909620951208.

Ezeibe, C. "Hate speech and electoral violence." A Paper. National Conference on General Elections in Nigeria: The Real Issues held at Electoral Institute Complex, Independent National Electoral Commission Annex, Central Business District, Abuja. 27- 2, July, 2015.

Ezeibe, C, Abada I. \& Okeke, M. "Zoning of public offices, liberal democracy and economic development in Nigeria." Mediterranean Journal of Social Sciences Vol.7, No.3 (2016): 328337. https://doi.org/10.5901/mjss.2016.v7n3slp328.

Ezeibe C. \& Ikeanyibe O.M. "Ethnic politics, hate speech, and access to political power in Nigeria." Africa Today, Vol.63, No.4 (2017): 65-83. https://doi.org/10.2979/africatoday. 63.4.04.

Ezeibe, C. "Hate Speech and Election Violence in Nigeria." Journal of Asian and African Studies (2020): 1-17. https://doi.org/10.1177/0021909620951208.

Esptein, G M. Good without God: What a Billion Nonreligious People Do Believe. New York: HarperCollins, 2010.

Fawole, O A \& Bello M L. "The Impact of Ethno-Religious Conflict on Nigerian Federalism.” International NGO Journal, Vol.6, No.10 (2011): 211-218. https://doi.org/11.5897/ NGOJ11.020.

Flew A (1979). "Golden rule". A Dictionary of Philosophy. London: Pan Books in association with The MacMillan Press. 
Granger, N. Marginalization: the pendulum swings both ways, 2013. https://www.saybrook.edu/ unbound/marginalization. Accessed 13 October, 2020.

Human Rights Watch. "Nigeria: Post-election violence killed 800." VoA News, 2011. https://www.voanews.com/africa/human-rights-watch-800-nigerians-killedelectoral-violence. Accessed 16 October 2020.

Human Rights Watch. "Nigeria: Post-election violence killed 800. HRW, 2011. https://www.hrw.org/news/2011/05/16/nigeria-post-election-violence-killed-800. Accessed 16 October 2020.

Ibeh, N. "58 Nigerians killed in 2015 pre-election violence so far - Rights Commission." Premium Times, 13 February 13 2015. https://www.premiumtimesng.com/news/head lines/176802-58-nigerians-killed-2015-pre-election-violence-far-rightscommission.html. Accessed 18 October 2020.

Ibenegbu, G. "Geopolitical zones in Nigeria and their states." NIGER.NG, 2017. https://www.naija.ng>Ask Naija. Accessed 25 July 2018.

Ifreke, I. "2019 election: Nigerians react to El-Rufai's alleged hate speech of putting foreigners in body bags." Daily Post, 2019. https://dailypost.ng/2019/02/06/2019-election-nigeriansreact-el-rufais-alleged-hate-speech-putting-foreigners-body-bags. Accessed 28 July 2019.

Ikeanyibe, O.M., C.C. Ezeibe, P.O. Mbah, \& C. Nwangwu. "Political Campaign and Democratisation: Interrogating the Use of Hate Speech in the 2011 and 2015 General Elections in Nigeria." Journal of Language and Politics, Vol.17, No.1 (2018): 92-117. https://doi.org/10.1075/jlp.16010.ike.

Irin News. "IRIN/Timeline of Boko Haram and related violence in Nigeria." Irin News, 2013. Available at: www.irinnews.org>news>2013/02. Accessed 15 March 2018.

Kamal, T O. "Chronology of Boko Haram attacks." The Guardian Nigeria, 13 December 2015. https://guardian.ng/news/chronology-of-boko-haram-attacks. Accessed 15April 2018.

Mamah, K E. "Boko Haram bombs Kano Afresh." Vanguard News, 24 January 2012. https://www.vanguardngr.com/2012/01/boko-haram-bombs-kano-afresh. Accessed 12 July 2018.

Mamah, K E. “Army, police planted Bombs in Mazi Nnamdi Kanu’s House-IPOB.” Vanguard, 2017. https://www.vanguardngr.com/2017/09/army-police-planted-bombs-mazi-nna mdi-kanus-house-ipob. Accessed 6 May 2018. 
Marama, N. "Timeline of Boko Haram attacks in Borno since May 2017." Vanguard, 2017. https://www.vanguardngr.com/2017/08/timeline-boko-haram-attacks-borno-sincemay-2017. Accessed 12 July 2018.

Merriam W. "Hate speech." Merriam Webster Dictionary, 2018. https://www.merriamwebster. com`hat. Accessed 5 May 2018.

Mbah, P.O., C. Nwangwu, S.C. Ugwu, \& G. Simons. "Contentious elections, political exclusion, and challenges of national integration in Nigeria." Cogent Social Sciences, Vol.5, No.1 (2019): 15656155. https://doi.org/10.1080/23311886.2019.1565615.

Mbah, P.O., C.N. Nzeadibe, C. Nwangwu, et.al. "Separatist threat, militarization and voter turnout: exploring the dynamics of the 2017 governorship election in Anambra state, Nigeria." Journal of Asian and African Studies. Vol.55, No.8 (2020): 1093-1107. https://doi.org/10.1177/0021909620907934.

n.n. "The new terror threat." The Day Live, 2016. https://www.thisdaylive.com/ index.php/2016/05/02/the-new-terror-threat/. Accessed 8 August 2018.

Nasir, S. "Nigerian girl talks about her escape from Boko Haram." Khaleej Times, 2017. https://m.khaleejtimes.com>general>ni. Retrieved on 7/4/2018.

Neisser, E. "Hate Speech in the New South Africa: Constitutional consideration for a land recovering from decades of rational repression and violence", South African Journal of Human Rights, Vol.10 (1994):33-356. https://doi.org/10.1177/0021909620951208.

National Bureau of Statistics. GDP 2020, 2020. https://www.nigerianstat.gov.ng. Accessed 19 October 2020.

News Agency of Nigeria. "I am happy my daughter didn't denounce Christ - father of only Dapchi girl in captivity." Vanguard, 2018. https:/www.vanguardngr.com>News. Accessed 5 May 2018.

Newsdiary. "Hate speech, fake news threats to general elections - CITAD.” News Diary, 2019. https://newsdiaryonline.com/2019-hate-speech-fake-news-threats-to-generalelections-citad. Accessed 23 March 2019.

Obijiofor, L. "Hate speech or Shutting Down Space for free Expression?" Sun News, 2018. https://www.sunnewsonline.com/hate-speech-or-shutting-down-space-for-freeexpression, 2018. Accessed 14 October 2020.

Odebode, N, A. Adepogbe, \& O. Aliko. "Niger Delta Agitators give Northerners, Yorubas Quit Notice.” Punch, 2017. https://punchng.com/ndelta-agitators-give-northernersyoruba-quit-notice. Accessed 26 July 2018. 
Ojo, A.O. Political Science and Government of Nigeria. Nigeria: Ilesanmi Press \& Sons, 1973.

Okoli, A. "Quit Notice to Igbo Security Threat, Crime Against the Nigerian State." Vanguard, 2017. http://www.vanguardngr.com>News. Accessed 4 May 2018.

Okoro, E N. A Nigerian Primary History. Lagos: Academic Press -Ltd, 1974.

Okoro, J P. "Herdsmen/farmers conflict and its effects on socio-economic development in Nigeria." Journal of Peace, Security, and Development, Vol.4, No.l (2018): 143-158.

Onah, N G. "Religious Pluralism and Sustainable National Development: The Nigerian experience." International Journal of Humanities and Social Sciences (IJHSS), Vol.3, No.1 (2014): 1-10.

Onah, N G \& L.N. Okwuosa. "Youth Unemployment and Peace in Nigerian Society." Mediterranean Journal of Social Sciences, Vol.7, No.l Sl (2016): 52-58. https://doi.org/10.5901/mjss.2016.v7nlslp52.

Opejobi, S. "Boko Haram attacks church in Borno, eight people killed." Daily Post, 2016. Available at: https://dailypost.ng/2016/09/19/breaking-boko-haram-attacks-church-borno-eightpeople-killed. Accessed 16 July 2018.

Opejobi, S. "Quit Notice: What we will do to Hausa/Fulani if any Igbo is Killed in the NorthIPOB." Daily Post, 2017. https://dailypost.ng/2017/06/26/quit-notice-will-hausafulanis-igbokilled-north-ipob/. Accessed 16 July 2018.

Opeyemi A.O. \& C. Haldun. "Ethnic and Religious Crises in Nigeria - A specific analysis upon identities (1999-2013)." African Journal on Conflict resolution. Vol.16, No.1 (2016): 87-110. https://www.ajol.info/index.php/ajcr/article/view/144735.

Oyedepo. "Fulani herdsmen declare war in violent letter to Oyedepo." Pulse, 2018. Available at: www.pulse.ng>communities>religion. Accessed 12 July 2018.

Premium Times. "INVESTIGATION: Herdsmen attacks claim 1,269 lives in Benue." Premium Times, 2016. https://www.premiumtimesng.com/news/headlines/208366-investigation -herdsmen-attacks-claim-1269-lives-benue.html. Accessed 11 November 2020).

Ray J I. "A Historical Survey of Ethnic conflict in Nigeria.” Asian Social Science, Vol.8, No.4 (2012): 13- 29. https://doi.org/10.5539/ass.v8n4pl3.

Sahara Reporters. "Niger Delta Avengers Threatens total shutdown of oil Production after ending ceasefire." Sahara Reporters, 2017. http://saharareporters.com/2017/11/03/nigerdelta-avengers-threaten-total-shutdown-oil-production-after-ending-ceasfire. Accessed 9 May 2018. 
Sahara Reporters. Nigerian Army launches "Exercise Python -dance II, set for crackdown on violent agitators, kidnappers, others in South-East." Sahara Reporters, 2017. Saharareporters.com>2017/09/09>Nigeria. Accessed 8 June 2018.

Sanni, K. “626 killed during 2019 Nigeria elections.” Report. Premium Times, July 30, 2019. https://www.premiumtimesng.com/news/headlines/343971-626-killed-during-2019nigeria-elections-report.html. Accessed 18 October 2020.

Skufca, L.C. "The golden rule (Ethic of reciprocity)." Camden Civil Rights Project, 2015. https:/camdencivilrightsproject.com/2015/1l/24/the-golden-rule-ethic-of-reciprocity. Accessed 21 October 2020.

Saxone, A. Abdulganiu A \& N. Lawrence. "16 Northern Groups gave Igbo October 1 to Vacate Region.” Vanguard, 2017. https:/guardian.ng/news/16-northern-groups-giveigbo-october-1-to-vacate-region. Accessed 26 July 2018.

The Nation Newspaper. "Timeline of Boko Haram attacks." The Nation Live, 2014. www.thenationonliveng.net timeline-of-boko. Accessed 17 July 2018.

Uja, E. "Herdsmen kill two priests, 11 others in Benue." The Nation Live, 2018. https://thenationonlineng.neg/herdsmen-kill-two-priests-ll-others-in-benue. Accessed 14 June 2018.

United Nations Committee on Elimination of Racial Discrimination. "General Recommendation No.35. Combating racist hate speech." CERD/C/GC/35, 26 September 2013. https://www.refworld.org/pdfid/53f457db4.pdf. Accessed 17 October 2020.

UNHCR. "Nigerian emergency." UNHCR, 2020. https://www.unhcr.org/nigeriaemergency.html. Accessed 12 November, 2020.

United Nations. "United Nations strategy and plan of action on hate speech." United Nations, 2019. https://www.un.org/en/genocideprevention/hate-speech-strategy.shtml. Accessed 2 February 2020.

Usifo, V. "13 causes of Ethnic Conflict in Nigeria and solutions." Info Guide Nigeria, 2017. https://infoguidenigeria.com/causes - ethnic-conflict. Accessed 30 June 2018.

Ushe, M.U. "Religious fanaticism and civil education in Nigeria: a paradigm for national development." Journal of Research in Education and Society, Vol.3, No.l (2012): 142-156.

Vanguard. Terror: 40 killed in Christmas bombings. 2011. https://www.vanguardngr.com/2011/12/terror-40-killed-in-christmas-bombings, 2011. Accessed 18 July 2018. 
Vanguard. Boko haram: The US House report (2). 2011. https://www.vanguardngr.com/2011/12/boko-haram-the-us-house-report-2. Accessed 19 July 2020.

Vanguard. Catalogue of attacks blamed on Boko Haram. 2012. https:/www.vanguardngr. com/2012/01/catalogue-of-attacks-blamed-on-boko-haram. Accessed 18 July 2018.

Vanguard. The Fulani Herdsmen threat to Nigeria's fragile unity, 2016. https://www.vanguardngr. com/2016/03/fulani-herdsmen-threat-nigerias-fragile-unity. Accessed 30 June 2018. 